\title{
Movement patterns of green turtles in Brazilian coastal waters described by satellite tracking and flipper tagging
}

\author{
B. J. Godley ${ }^{1, *}$, E. H. S. M. Lima ${ }^{2}$, S. Åkesson ${ }^{3}$, A. C. Broderick ${ }^{1}$, F. Glen ${ }^{1}$, \\ M. H. Godfrey ${ }^{4}$, P. Luschi ${ }^{5}$, G. C. Hays ${ }^{1}$ \\ ${ }^{1}$ Marine Turtle Research Group, School of Biological Sciences, University of Wales, Swansea SA2 8PP, Wales, UK \\ ${ }^{2}$ Fundação Pró-TAMAR, Caixa Postal 01, 62-592-990, Almofala, Ceará, Brazil \\ ${ }^{3}$ Department of Animal Ecology, Lund University, Ecology Building, 22362 Lund, Sweden \\ ${ }^{4}$ North Carolina Wildlife Resources Commission, 307 Live Oak Street, Beaufort, North Carolina 28516, USA \\ ${ }^{5}$ Dipartimento di Etologia, Ecologia, Evoluzione, University of Pisa, Via A. Volta 6, 56126 Pisa, Italy
}

\begin{abstract}
The movements of 8 green turtles Chelonia mydas in Brazilian coastal waters were tracked using transmitters linked to the Argos system for periods of between 1 and $197 \mathrm{~d}$. These were the first tracking data gathered on juveniles of this species in this important foraging ground. Information was integrated with that collected over a decade using traditional flipper-tagging methods at the same site. Both satellite telemetry and flipper tagging suggested that turtles undertook 1 of 3 general patterns of behaviour: pronounced long range movements ( $>100 \mathrm{~km})$, moderate range movements $(<100 \mathrm{~km})$ or extended residence very close to the capture/release site. There seemed to be a general tendency for the turtles recaptured/tracked further afield to have been among the larger turtles captured. Satellite tracking of 5 turtles which moved from the release site showed that they moved through coastal waters; a factor which is likely to predispose migrating turtles to incidental capture as a result of the prevailing fishing methods in the region. The movements of the 3 turtles who travelled less than $100 \mathrm{~km}$ from the release site challenge previous ideas relating to home range in green turtles feeding in sea grass pastures. We hypothesise that there may be a fundamental difference in the pattern of habitat utilisation by larger green turtles depending on whether they are feeding on seagrass or macroalgae. Extended tracking of 2 small turtles which stayed near the release point showed that small juvenile turtles, whilst in residence in a particular feeding ground, can also exhibit high levels of site-fidelity with home ranges of the order of several square kilometers.
\end{abstract}

KEY WORDS: Marine turtle $\cdot$ Chelonia mydas $\cdot$ Migration $\cdot$ Feeding $\cdot$ Mark-recapture $\cdot$ Home range Incidental catch

\section{INTRODUCTION}

Successful conservation of large marine vertebrates requires an adequate understanding of their temporal and spatial distributions, migratory patterns and habitat utilisation. This information allows the assessment of likely interactions with fisheries and other threats, as well as the designation of key areas to be protected or subject to management regimes. All marine turtle species in the Atlantic are considered threatened or endangered, mandating protective measures through national legislation and international agreements. However, this is not a simple task in this particularly enigmatic group, which spend most of their life at sea below the surface, tending to migrate long distances among disparate developmental, breeding and adult feeding habitats (Bolten \& Balazs 1995, Bjorndal \& Bolten 1997, Miller 1997, Musick \& Limpus 1997). 
For decades, the main tool used to gain insights into the distribution and movements of sea turtles was flipper tagging (Hendrickson 1958) and a great deal has been learned from this technique. Flipper tagging of nesting adults has given insights into reproductive behaviour (Miller 1997), pre- and post-breeding migrations (Carr et al. 1978, Balazs 1980, Limpus et al. 1992). Tagging of juveniles has given preliminary insights into habitat utilisation (Schmid 1995), growth rates (Boulon \& Frazer 1990, Limpus \& Chaloupka 1997) and ontogenetic migrations (Bjorndal \& Bolten 1997, Musick \& Limpus 1997). However, as a result of recent technical advancements, the exploitation of 2 novel technologies has allowed greater steps to be made in the understanding of the ecology of turtles. Firstly, the molecular genetics revolution has given insights into the biology of species, populations and turtles, elucidating key aspects essential to their conservation and management, e.g. confirming a general pattern of natal philopatry in females (Bowen et al. 1992) and males (FitzSimmons et al. 1997), allowing an assessment of breeding colony of origin in mixed stocks (Lahanas et al. 1998, Bass \& Witzell 2000), and assessment of the likely impact of specific fisheries (Laurent et al. 1998). Secondly, the increased performance and reduction in size of satellite tracking units has allowed them to become of great utility in turtle tracking studies. Using satellite transmitters, it has been possible to detail the post-reproductive migration routes of adult females and males (Morreale et al. 1996, Sakamoto et al. 1997, Balazs \& Ellis 2000, Hatase et al. 2002a,b) and to ascertain the location and usage of foraging grounds of adult turtles, in neritic (Godley et al. 2002b, 2003) and pelagic areas (Hughes et al. 1998, Nichols et al. 2000). The remote assessment of habitat utilisation by juveniles at a few sites has also been demonstrated (Renaud \& Carpenter 1994, Polovina et al. 2000, Bentivegna 2002).

The green turtle Chelonia mydas is found worldwide in tropical and subtropical waters (Hirth 1997), with molecular evidence suggesting that the Atlantic and Indo-Pacific populations are discrete and structured (Bowen et al. 1992). In the Atlantic, together with numerous areas where small numbers of green turtles nest, several major nesting colonies exist: Tortuguero, Costa Rica (Bjorndal et al. 1999); Ascension Island, UK (Mortimer \& Carr 1987); Suriname (Schulz 1975); Aves Island, Venezuela (Sole \& Medina 1989); Poilao, Guinea Bissau (Catry et al. 2002); Trinidade, Brazil (Moreira et al. 1995), Bioko, Equatorial Guinea (Tomas et al. 1999) and a sizeable population is thought to nest in French Guiana (M. Girondot pers. comm.) Green turtles have traditionally been widely exploited for their eggs, shell and flesh which are used for both food and medicinal purposes (Parsons 1962). Despite the reduction of many populations due to over-exploitation (King 1982), other populations afforded extensive protection appear to be relatively stable or growing (Bjorndal et al. 1999, Godley et al. 2001).

There is a paucity of knowledge of the ecology of Atlantic green turtles away from the nesting grounds, although it apparently involves movements over great spatial and temporal scales (Musick \& Limpus 1997). All available evidence suggests it takes decades for green turtles to reach adulthood (Limpus \& Chaloupka 1997). Although detailed direct evidence is lacking (Bolten \& Balazs 1995) it is assumed that, like loggerhead turtles Caretta caretta (Musick \& Limpus 1997), hatchling green turtles disperse into an oceanic phase where they stay for several years before settling into neritic benthic habitats as herbivores, when they reach curved carapace lengths (CCL) in the region of 25 to $35 \mathrm{~cm}$ (Bjorndal 1980, Musick \& Limpus 1997). Feeding-ground assemblages of juveniles have been shown to consist of turtles from different, spatially separated nesting populations (Lahanas et al. 1998, Bass \& Witzell 2000). However, not all juveniles appear to stay as permanent residents, with many undertaking extensive developmental migrations (Bjorndal \& Bolten 1997, Musick \& Limpus 1997), possibly as a response to differing population density and/or forage abundance and quality (Bjorndal et al. 2000).

The importance of the wide coastal shelf of tropical Brazil as a habitat for adult green turtles has been emphasised repeatedly, with turtles tagged nesting in Ascension Island and the Guianas being recovered there (Pritchard 1973, 1976, Mortimer \& Carr 1987, Luschi et al. 1998). However, the area not only hosts adult turtles but also large numbers of juveniles (Lum et al. 1998, Lima 1999, Lima et al. 1999) that feed on the abundant macroalgae found in the region (Ferreira 1968). Although directed small-scale traditional fisheries for marine turtles once existed in Brazil (Pritchard 1976), they are no longer in operation (Marcovaldi \& Marcovaldi 1999), and all marine turtle species are legally protected with few cases of illegally directed take. Turtles are, however, still incidentally caught in fishing gear. A national programme of marine turtle conservation exists in the Brazilian feeding grounds with a goal to reduce mortality resulting from catch by some artisanal fisheries (Marcovaldi et al. 1998, 2001). Many turtles are still caught alive, especially in the fishing weirs (currais) found along the coastline of the state of Ceará. These are non-selective traps (up to $2 \mathrm{~km}$ long and $10 \mathrm{~m}$ deep) placed perpendicular to the shore designed to funnel fish into a catching area in which they can be captured or are stranded as the tide recedes (Seraine 1958). These turtles are usually alive and uninjured. As a result of collaboration between conservationists and the small fishing community in Almofala, 
capture, mark and release of 419 turtles has been possible since 1992 (E. H. S. M. Lima 1999 unpubl. data).

The unique circumstances at Almofala offered us the opportunity of undertaking a direct comparison of 2 methods of studying the movements of green turtles. We could undertake satellite tracking of a number of turtles, integrating our findings with the results of tag recaptures of turtles released at this same site. Our fundamental objective was to identify whether turtles showed fidelity to certain localised sites and/or undertook long-distance movements which might make them more susceptible to capture in marine fisheries.

\section{MATERIALS AND METHODS}

The present study was carried out at the Projeto TAMAR turtle research station at Almofala, state of Ceará, Brazil, where a mark and recapture study of green turtles has been in operation since 1992. All study animals were captured at sea by fishermen and brought to the TAMAR station for assessment. All had been captured in waters around Almofala except Turtle A which was captured $242 \mathrm{~km}$ to the east in Fortaleza and brought to the station for recording and release. Turtles were then maintained in captivity for varying periods ranging from a few hours to $230 \mathrm{~d}$. Data recorded in each case included morphometrics (CCL and CCW [curved carapace width] in cm, Bolten [1999]; body weight in $\mathrm{kg}$ ). All turtles were then tagged on the trailing edge of both fore-flippers (Inconel tags model 681C, National Band).

We attached Telonics model ST-18 platform terminal transmitters (PTTs) to 8 green turtles (Turtles A-H) between July 2000 and May 2001. The carapace was first cleaned using mildly abrasive sandpaper, then wiped with acetone to remove natural oils. The PTTs were attached using a 2 part epoxy resin (Foilfast, SFS Stadler) according to a methodology used previously (Godley et al. 2002b). Attention was paid to make the attachment package hydrodynamic to minimise drag (Watson \& Granger 1998). Transmitters were tracked using the Argos system resulting in fixes of variable accuracy (Argos 1996). Routes were plotted using locations of Classes 3, 2, 1 and A after data presented by Argos (Argos 1996), and recent work (Hays et al. 2001) has shown these to be the most reliable. Locations were further filtered whereby those locations were discarded if their inclusion implied a swimming speed between successive fixes of $>5 \mathrm{~km} \mathrm{~h}^{-1}$ (see Luschi et al. 1998, 2001).

\section{RESULTS}

\section{Study animals}

Study animals measured from 41 to $116 \mathrm{~cm} \mathrm{CCL}$ (Table 1). This range encompasses the ranges from relatively small post-pelagic juveniles to adults in some of the nesting populations that have been shown to contribute to the stocks of green turtles in Brazilian coastal waters (Hirth 1997). None of the turtles exhibited the sexually dimorphic traits of adult males (reviewed by Godley et al. 2002a). It is almost certain that Turtles A, $\mathrm{B}, \mathrm{C}$ and $\mathrm{H}$ were juvenile. There is a slight possibility that Turtles E and F could have been small adult females but only D and G are likely to have been adult. A clear relationship between CCL and bodyweight was established for the first time in this region (Fig. 1).

\section{Transmitter performance and satellite tracking data}

There was great variation in the duration of tracking (range 1 to $197 \mathrm{~d}$ ). Although we should interpret the

Table 1. Chelonia mydas. Body measurements, period of captivity, release date and transmitter performance of turtles subject to satellite tracking. Number of locations are broken down into the number of each class: 3, 2, 1, 0, A, B (see text for details). (CCL: curved carapace length, CCW: curved carapace width)

\begin{tabular}{|c|c|c|c|c|c|c|c|c|c|c|c|c|c|}
\hline \multirow[t]{2}{*}{ Turtle } & \multirow{2}{*}{$\begin{array}{l}\mathrm{CCL} \\
(\mathrm{cm})\end{array}$} & \multirow{2}{*}{$\begin{array}{l}\mathrm{CCW} \\
(\mathrm{cm})\end{array}$} & \multirow{2}{*}{$\begin{array}{l}\text { Body } \\
\text { weight } \\
(\mathrm{kg})\end{array}$} & \multirow{2}{*}{$\begin{array}{l}\text { Period } \\
\text { in } \\
\text { captivity } \\
\text { (d) }\end{array}$} & \multirow{2}{*}{$\begin{array}{l}\text { Release } \\
\text { date }\end{array}$} & \multirow{2}{*}{$\begin{array}{l}\text { Duration } \\
\text { of trans- } \\
\text { missions } \\
\text { (d) }\end{array}$} & \multicolumn{7}{|c|}{ No. locations in each class } \\
\hline & & & & & & & 3 & 2 & 1 & 0 & A & B & Total \\
\hline A & 54 & 47 & 16.5 & 230 & $11 \mathrm{Jul} 00$ & 22 & 1 & 5 & 8 & 9 & 27 & 34 & 84 \\
\hline B & 53 & 45 & 14.5 & $<1$ & $17 \mathrm{Jul} 00$ & 96 & 0 & 1 & 2 & 0 & 23 & 173 & 199 \\
\hline $\mathrm{C}$ & 41 & 36 & 6.5 & 17 & 19 Jul 00 & 197 & 1 & 2 & 6 & 0 & 20 & 275 & 304 \\
\hline $\mathrm{D}$ & 116 & 108 & 190 & $<1$ & 11 Jan 01 & 64 & 0 & 0 & 1 & 0 & 4 & 6 & 11 \\
\hline E & 89 & 83 & 15 & 83 & 03 Mar 01 & 1 & 0 & 1 & 2 & 5 & 1 & 1 & 10 \\
\hline $\mathrm{F}$ & 92 & 82 & 74.5 & $<1$ & 19 Apr 01 & 54 & 0 & 2 & 2 & 5 & 27 & 71 & 107 \\
\hline $\mathrm{G}$ & 106 & 96 & 145 & $<1$ & 20 May 01 & 83 & 2 & 5 & 9 & 3 & 24 & 96 & 139 \\
\hline $\mathrm{H}$ & 76 & 71 & 54 & $<1$ & 20 May 01 & 43 & 0 & 2 & 1 & 8 & 25 & 120 & 156 \\
\hline
\end{tabular}




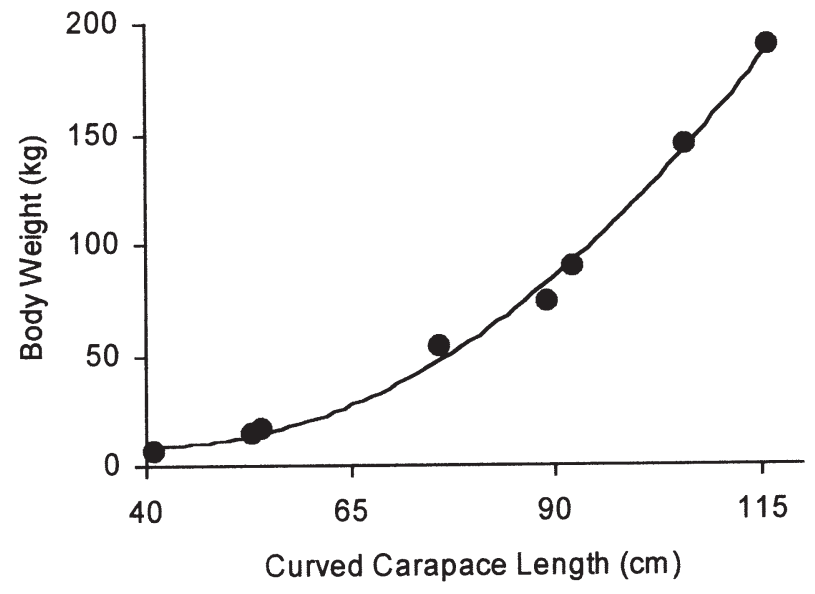

Fig. 1. Chelonia mydas. Relationship between curved carapace length (CCL) and body weight of green turtles in Brazilian coastal waters. (Regression: body weight $=0.06 \mathrm{CCL}^{2}-$ $\left.7.35 \mathrm{CCL}+219 F_{1,7}=28.5, \mathrm{r}^{2}=0.92, \mathrm{p}<0.01\right)$

result of such small data sets with caution, the duration of tracking was not significantly related to body size (CCL, CCW, body weight; regression $\mathrm{p}>0.05$ ). Satellite tracking data provided useful insights into the behaviour of all but 1 turtle (Turtle E) for which transmission stopped during the first day after release. The movements of this turtle will not be considered any further. In general, it appeared that turtles undertook 1 of 3 general patterns of behaviour: (1) pronounced longrange movements $(>100 \mathrm{~km}$; Turtles A and F); (2) moderate-range movements $(<100 \mathrm{~km}$; Turtles $\mathrm{D}, \mathrm{G}$ and $\mathrm{H})$; (3) extended residence very close to the capture/ release site (Turtles B and C). We explore the movements of the turtles in each of these 3 categories in turn.

\section{Long-range movements}

Upon release, Turtle A, originally captured in Fortaleza, travelled over $20 \mathrm{~km}$ offshore, before returning to within a few $\mathrm{km}$ of the release point after $30 \mathrm{~h}$ (Fig. 2a and insert). It then began to travel along the coast in a generally westerly direction i.e. in the opposite direction to that of its original capture site. It kept up this course for $10 \mathrm{~d}$ until its capture by fishermen on 23 July. We infer its capture at this point based on 3 criteria: (1) location accuracy started to increase, with more frequent high-quality fixes being received; $(2)$ there was an obvious switch in time spent at the surface generated from data given by the inbuilt surface counter on the PTT from $<1$ to $100 \%$ of time on the surface, within 2 successive uplinks $2 \mathrm{~h}$ apart; (3) high quality fixes were obtained inland near the town São Luis (mean location from 52 fixes of location class [LC] 1,2 or 3: $2.8^{\circ} \mathrm{S}, 318.2^{\circ} \mathrm{E}$ ) for a further $11 \mathrm{~d}$ before transmissions failed. This capture was subsequently confirmed by government officials (pers. comm. to E. H. S. M. Lima). During the $255.2 \mathrm{~km}$ journey of this turtle, the transmitter performed well, with 84 locations $\left(7\right.$ locations $\left.\mathrm{d}^{-1}\right)$, of which $14(17 \%)$ were of LC 1,2 and 3.

Upon release, Turtle F headed in a generally southeastern direction, its route closely following the coastline, as per Turtle A (Fig. 2b). During the journey of this turtle, only 4 ( $4 \%$ of the total) locations were of LC 1,2 or 3 , although an average of 2.0 locations $\mathrm{d}^{-1}$ were received. After travelling over $670 \mathrm{~km}$ along the Brazilian Coast, the turtle appeared to end its journey and take up residency at the point of the last high quality location (at an area in the region of $5.3^{\circ} \mathrm{S}, 324.7^{\circ} \mathrm{E}$ ) from where we received occasional locations until transmissions failed 29 d later.

\section{Moderate-range movements}

Three turtles (D, G and $H$ ) undertook moderate range movements during 64,83 and $43 \mathrm{~d}$ of tracking,

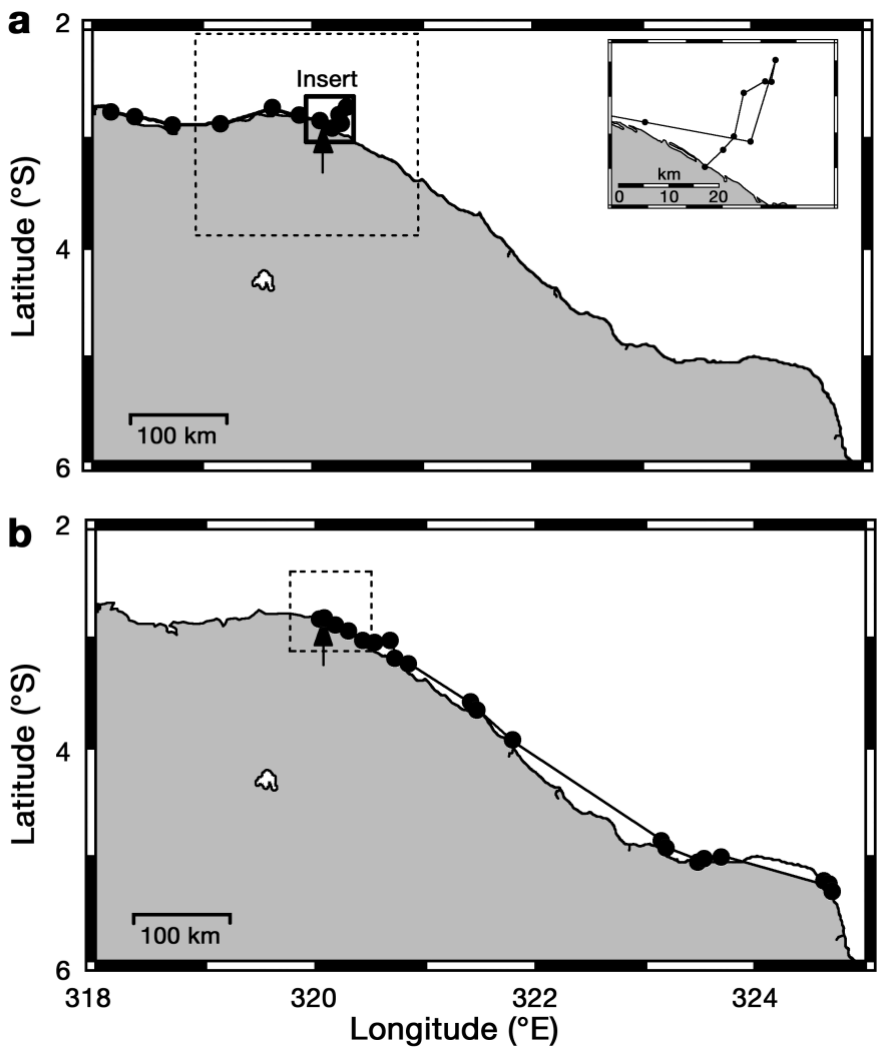

Fig. 2. Chelonia mydas. Tracking results for turtles which undertook longer range movements (>100 km). (a) Turtle $A_{\text {; }}$ (b) Turtle F. Note the boxes made of broken lines in (a) and (b) correspond to the geographic coverage of Figs. $3 \& 5$, respectively. Arrow indicates release site at Almofala. Box made of solid line in (a) corresponds to inset map 

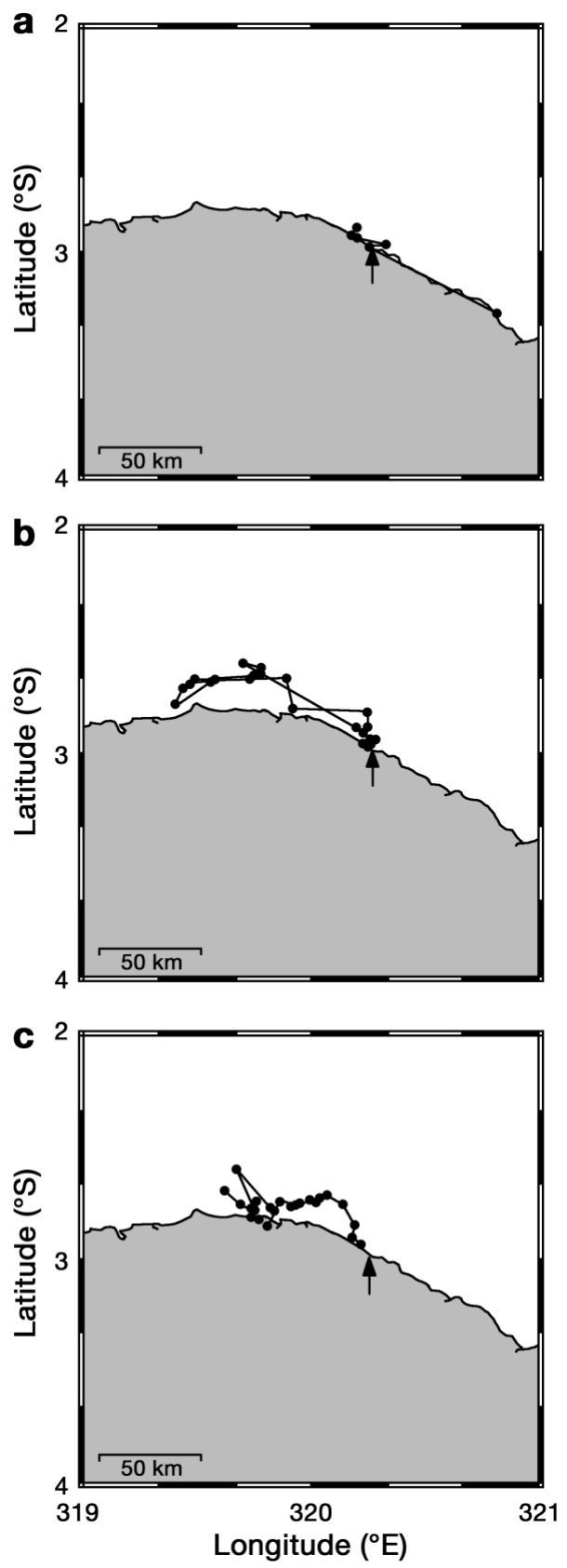

Fig. 3. Chelonia mydas. Tracking results for turtles which undertook medium range movements $(<100 \mathrm{~km})$. (a) Turtle $D_{\text {; }}$ (b) Turtle $G_{;}$(c) Turtle $H$. Arrow indicates release site at Almofala

respectively (Fig. 3). Despite substantial variation in mean transmitter performance $(0.2,1.7$ and 3.6 locations $\mathrm{d}^{-1}$, respectively) we were still able to track each turtle. All locations placed the turtles in relatively nearshore waters. Turtle D initially moved to the west and then to the south-east, with the track ending at a point some $80 \mathrm{~km}$ from the capture/ release site. Turtle G moved approximately $90 \mathrm{~km}$ in a westerly direction before returning to the vicinity of the capture/release site. Turtle $\mathrm{H}$ moved between the release site and a point some $65 \mathrm{~km}$ west of the capture/release site.

\section{Speed of movement}

To investigate the speed of movement in our study animals we were posed with the problem of slow moving turtles being tracked using locations of a generally low accuracy. Cumulative error throughout the journey can potentially obscure the true patterns of variability in speed of movement. To counter this problem we simply looked at the displacement calculated using a great circle route equation between each fix and the release site. In the 5 turtles that moved perceptible distances from the release site (Turtles A and D to $H$ ), the dichotomy of distance moved is mirrored in the relative speed of movement (i.e. the slope of the lines in Fig. 4). Turtles D, G and H, although travelling away from the release site, typically did so at a speed of less than $2 \mathrm{~km} \mathrm{~d}^{-1}$. Turtles A and F set off from the release site at speeds of the order of $1 \mathrm{~km} \mathrm{~h}^{-1}$. This was maintained at a relatively constant rate until in the case of Turtle A it was captured, and in the case Turtle F it took up residency after $23 \mathrm{~d}$.

\section{Extended residence}

Both Turtles B and C swam offshore very close to the release point where it appears they stayed for the duration of the subsequent tracking of 96 and $197 \mathrm{~d}$,

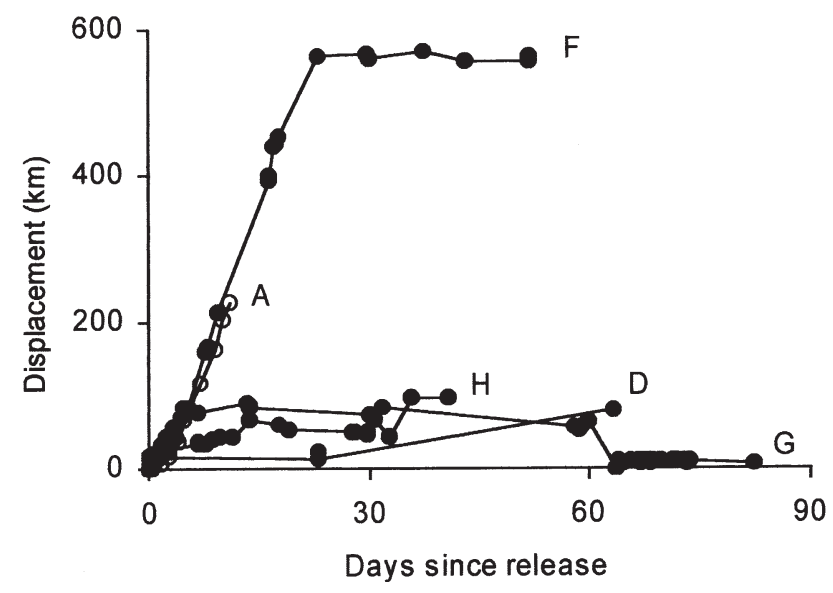

Fig. 4. Chelonia mydas. Displacement versus time for all the turtles that moved away from the release site (Turtles A, D, F, $\mathrm{G}$ and $\mathrm{H}$ ). Turtle trajectories are labelled on the graph, with open circles representing data from Turtle A 
respectively (Fig. 5). Both transmitters functioned well, yielding 199 fixes for Turtle B and 304 fixes for Turtle C (2.1 and 1.5 fixes $\mathrm{d}^{-1}$, respectively). However, only 3 fixes for Turtle B and 9 fixes for Turtle C were of LC 1, 2 or 3 . The detailed performance of these transmitters
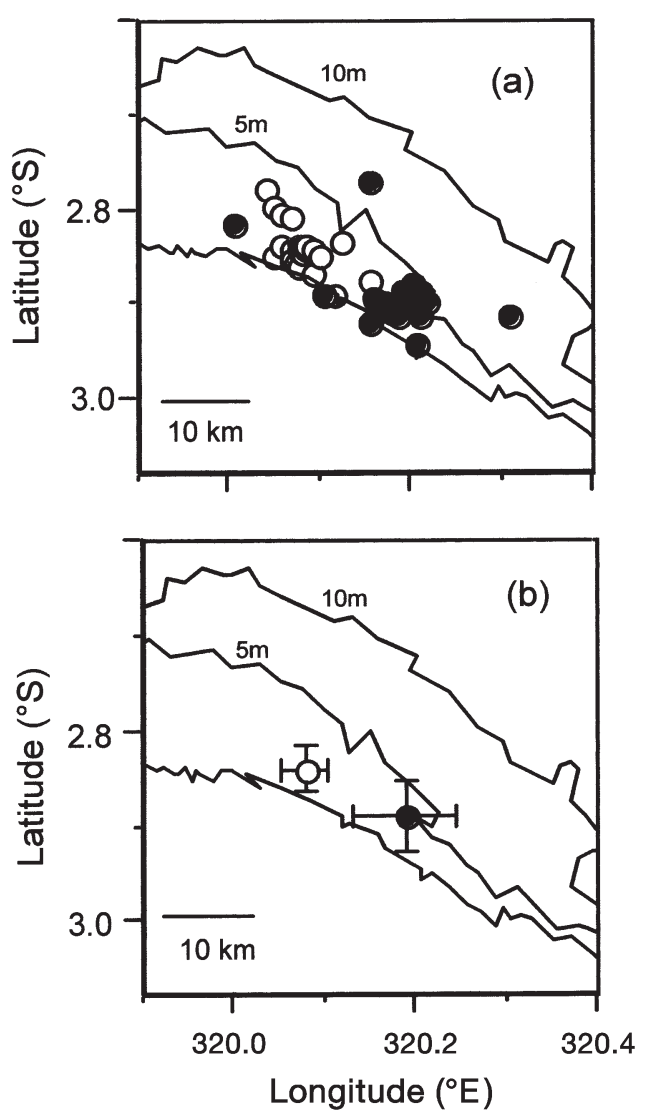

Fig. 5. Chelonia mydas. Tracking results for Turtles B and C that stayed close to Almofala: (a) the distribution of LC 3, 2, 1 and $\mathrm{A}$ (see text) and (b) the mean position of LC A \pm 1 SD. LC 3,2 and 1 fell within these error bars for each turtle. Filled symbols $=$ Turtle $B_{;}$open symbols $=$Turtle $C$. Lines signify the coastline and the 5 and $10 \mathrm{~m}$ isobaths is given in Table 2 in comparison with fixes from a stationary transmitter of known position calculated by Hays et al. (2001). Although there was a slight overlap in LC A for the 2 turtles, this was minimal. LC 1, 2 and 3 locations fell within $1 \mathrm{SD}$ of the mean of LC A locations. Home ranges of both turtles were centered between the shoreline and the $5 \mathrm{~m}$ isobath.

Two factors will contribute to the scatter of locations for the 2 turtles that stayed near Almofala: (a) inaccuracies in the calculated locations and (b) movements of the turtles. We implemented an analytical approach to partition the importance of these 2 effects. First we have already quantified the error of fixes with LC A and B for a transmitter at similar latitude (Hays et al. 2001), with trials of PTTs in fixed locations showing that the standard deviations of longitudinal and latitudinal errors $\left(\sigma_{x}\right.$ and $\sigma_{y}$ respectively) are 0.81 and $1.39 \mathrm{~km}$ respectively for $\mathrm{LC} \mathrm{A}$, and 7.79 and $5.23 \mathrm{~km}$ respectively for LC B. Given the relatively poor accuracy of LC $B$, we omitted them from the following calculations. For each turtle we assumed that the movements occurred in a home range that was defined by a bivariate normal distribution, with potentially different standard deviations for the longitudinal and latitudinal components $\left(\mathrm{h}_{\mathrm{x}}\right.$ and $\mathrm{h}_{\mathrm{y}}$ respectively). We then simulated the scatter of locations that would be achieved using the measured values for $\sigma_{X}$ and $\sigma_{Y}$ for LC A and different values for $\mathrm{h}_{x}$ and $\mathrm{h}_{\mathrm{y}}$. These simulations showed that for Turtle B, when $\mathrm{h}_{x} \approx 2.3 \mathrm{~km}$ and $\mathrm{h}_{y} \approx 1.7 \mathrm{~km}$, then the modelled distribution of Class A locations closely matched those observed. Similarly for Turtle $C$ the values of $h_{X} \approx$ $5.0 \mathrm{~km}$ and $\mathrm{h}_{\mathrm{y}} \approx 2.0 \mathrm{~km}$ reproduced the observed scatter of locations. Although this approach is clearly simplistic (for example the turtle home ranges may not follow a bivariate normal distribution and we only have an approximate estimate of the accuracy of LC A locations), the implication of these calculations is that these turtles made only small range movements during the study period over an area of a few square kilometres.

Table 2. Chelonia mydas. Transmitter performance on Turtles B and C. For each location class (LC) and all fixes combined, the mean latitude (Lat) and mean longitude (Long) is calculated and SD (in km) is given in parentheses. For illustrative purposes the mean deviation (in $\mathrm{km}$ ) for fixes of a stationary transmitter in a known position as calculated by Hays et al. (2001) is given for each of the different location classes. For all calculations the sample size (n) is given. Note: no Class 0 locations were obtained for Turtles B and C in this study

\begin{tabular}{|c|c|c|c|c|c|c|c|c|c|}
\hline \multirow{2}{*}{$\begin{array}{l}\text { Location } \\
\text { class (LC) }\end{array}$} & \multirow[b]{2}{*}{ Lat } & \multirow{2}{*}{$\begin{array}{l}\text { Turtle B } \\
\text { Long }\end{array}$} & \multirow[b]{2}{*}{$\mathrm{n}$} & \multirow[b]{2}{*}{ Lat } & \multirow{2}{*}{$\begin{array}{c}\text { Turtle C } \\
\text { Long }\end{array}$} & \multirow[b]{2}{*}{$\mathrm{n}$} & \multicolumn{3}{|c|}{ Hays et al. (2001) } \\
\hline & & & & & & & Lat & Long & $\mathrm{n}$ \\
\hline 3 & - & - & 0 & 2.90 & 39.80 & 1 & 0.12 & 0.32 & 38 \\
\hline 2 & 2.84 & 39.93 & 1 & $2.90(0.1)$ & $39.80(0.5)$ & 2 & 0.28 & 0.62 & 28 \\
\hline 1 & $2.85(0.4)$ & $39.94(2.2)$ & 2 & $2.90(1.0)$ & $39.81(1.7)$ & 6 & 1.03 & 1.62 & 19 \\
\hline A & $2.84(2.8)$ & $39.92(2.8)$ & 23 & $2.89(4.0)$ & $39.81(6.2)$ & 20 & 1.39 & 0.81 & 18 \\
\hline B & $2.84(6.9)$ & $39.92(9.3)$ & 173 & $2.90(6.1)$ & $39.79(9.8)$ & 275 & 5.23 & 7.79 & 22 \\
\hline Overall & $2.84(6.52)$ & $39.92(8.9)$ & 199 & $2.90(4.6)$ & $39.80(9.4)$ & 304 & - & - & - \\
\hline
\end{tabular}




\section{Patterns of movement from tagging}

Data regarding green turtles tagged at Almofala have been briefly reviewed by Lima (1999) and are summarised in Table 3. Of 419 turtles tagged and released since 1992, there have been 16 recaptures at intervals ranging from 18 to $1306 \mathrm{~d}$. Although the majority of recaptures were at Almofala $(n=12)$, 2 were from Jericoacoara, Brazil, and there were 2 long-range tag returns from the Northern Hemisphere: (1) Miskito Keys, Nicaragua (Lima et al. 1999) and (2) Mayaro, Trinidad and Tobago (Lum et al. 1998). At the time of initial capture, turtles which were subsequently recaptured at Almofala were significantly smaller than those which apparently moved further afield and were recaptured elsewhere (Mann Whitney $W=83, \mathrm{p}<0.05$; Almofala: median $45 \mathrm{~cm}$; elsewhere: median $54.5 \mathrm{~cm}$; Table 3 ). In addition, the mark-recapture interval was greater in those turtles recaptured at other sites (Mann Whitney $W=82$, p < 0.05, Almofala: median $81.5 \mathrm{~d}$; elsewhere: median $371.5 \mathrm{~d})$.

\section{DISCUSSION}

Our main finding in this study was that for green turtles captured in and released from marine fisheries of Ceará, Brazil, there appear to be 3 main patterns in behaviour: residency with a high level of site-fidelity, medium-range movements $(<100 \mathrm{~km})$ and long-range

Table 3. Chelonia mydas. Data regarding green turtles tagged at Almofala that were subsequently recaptured. CCL: curved carapace length; Alm: Almofala, Brazil; Nic: Miskito Keys, Nicaragua $\left(14.5^{\circ} \mathrm{N}, 274.8^{\circ} \mathrm{E}\right.$; Lima et al. 1999); T\&T: Mayaro, Trinidad and Tobago $\left(10.2^{\circ} \mathrm{N}, 299.0^{\circ} \mathrm{E}\right.$, Lum et al. 1998); Jer: Jericocoara, Brazil $\left(2.8^{\circ} \mathrm{S}, 319.5^{\circ} \mathrm{W}\right)$. Distance: minimum distance $(\mathrm{km})$ from Almofala

\begin{tabular}{|c|c|c|c|c|c|c|}
\hline \multicolumn{2}{|c|}{ Capture } & \multirow[b]{2}{*}{ Location } & \multirow{2}{*}{$\begin{array}{c}\text { Date } \\
(\mathrm{dd} / \mathrm{mm} / \mathrm{yy})\end{array}$} & \multirow{2}{*}{$\begin{array}{l}\text { apture } \\
\text { CCL } \\
(\mathrm{cm})\end{array}$} & \multirow[b]{2}{*}{$\begin{array}{l}\text { Days at } \\
\text { large }\end{array}$} & \multirow[b]{2}{*}{ Distance } \\
\hline $\begin{array}{l}\text { Date } \\
\text { (dd/mm/yy) }\end{array}$ & $\begin{array}{l}\text { CCL } \\
(\mathrm{cm})\end{array}$ & & & & & \\
\hline 23/03/94 & 43 & Alm & $22 / 06 / 94$ & 43 & 91 & - \\
\hline 03/08/94 & 88 & $\mathrm{Nic}$ & 01/03/98 & - & 1306 & 4500 \\
\hline 09/07/95 & 41 & Alm & 04/03/96 & 59 & 239 & - \\
\hline $23 / 02 / 96$ & 41 & Alm & 04/03/96 & 41 & 10 & - \\
\hline $23 / 02 / 96$ & 41 & Alm & 09/05/96 & 44 & 76 & - \\
\hline 04/03/96 & 52 & Alm & $30 / 04 / 96$ & 52 & 57 & - \\
\hline 04/03/96 & 52 & Alm & $30 / 05 / 96$ & 55 & 87 & - \\
\hline $14 / 03 / 96$ & 50 & Alm & 05/04/96 & 50 & 22 & - \\
\hline 17/04/96 & 44 & Alm & 05/05/96 & 44 & 18 & - \\
\hline 06/06/96 & 48 & $\mathrm{~T} \& \mathrm{~T}$ & 03/11/97 & 56 & 515 & 2700 \\
\hline 05/02/98 & 45 & Alm & $11 / 04 / 98$ & 47 & 65 & - \\
\hline 05/02/98 & 45 & Alm & 09/05/98 & 47 & 93 & - \\
\hline 05/02/98 & 45 & Alm & $30 / 05 / 98$ & 47 & 114 & - \\
\hline 05/02/98 & 45 & Alm & 06/07/98 & 47 & 151 & - \\
\hline 13/03/98 & 51 & Jer & 27/10/98 & 56 & 228 & 80 \\
\hline 14/07/98 & 58 & Jer & 27/10/98 & 56 & 105 & 80 \\
\hline
\end{tabular}

movements $(>100 \mathrm{~km})$. These differences were highlighted by results from both traditional flipper-tagging methodologies and the more novel use of satellite tracking. Our findings are at least in part consistent with available information regarding the behaviour and ecology of green turtles at other neritic feeding grounds where turtles are usually found foraging in shallow inshore waters and show site-fidelity with limited home ranges (Bjorndal 1980, Ogden et al. 1983, Brill et al. 1995).

The single major difference in our findings from those previously undertaken on green turtle foraging is that 3 animals had what we suggest are very large home ranges. The 3 turtles undertaking medium range movements did so in a manner not suggestive of shuttling between sites or migration. Movement in these turtles were less that $2 \mathrm{~km} \mathrm{~d}^{-1}$ and in 2 cases the turtle returned to the vicinity of the release site, 1 having been as far as $90 \mathrm{~km}$ away. We suggest that the home range for some turtles feeding on macroalagae in the Brazilian neritic may encompass an area which spans up to $90 \mathrm{~km}$ of coastline. This contrasts markedly with green turtles in seagrass beds where direct observations have shown that turtles maintain distinct gardens that they serially crop, so encouraging new (and energetically rich) growth (Bjorndal 1980, 1997). Although still showing high levels of fidelity, green turtles tracked by radio and sonic telemetry in a coastal algal foraging area in the Gulf of California showed home ranges larger than those previously estimated (Seminoff et al. 2002 and references therein). We suggest that there may be a fundamental dichotomy in green turtle home range dependent on whether the diet is predominantly seagrass or algae, with home ranges being larger in algal pastures.

Two turtles showed a very high level of site-fidelity, and we investigated the quantification of the size of their home ranges. Rigorous techniques for identifying home ranges from Argos data have recently been applied to wandering albatrosses (Wood et al. 2000). However, in this case many high quality locations were obtained (since the birds do not dive, and live at high latitudes where the frequency of satellite overpasses is greater) and the movements were extensive, leading to home-range estimates of the order of $100000 \mathrm{~s}$ of $\mathrm{km}^{2}$. In contrast, while it is easy to identify small-scale movements in general terms from Argos data, i.e. all locations in generally the same area, 
rigorously defining a home range in these cases is problematic since location error may obscure an animal's actual movements. This problem is exasperated for marine turtles since their diving behaviour leads to a dominance of low quality locations when they are not travelling (e.g. Plotkin 1998). It has been suggested that novel analytical techniques will need to be implemented to solve this problem of quantifying smallscale movements using Argos data (Deutsch et al. 1998). The approach we implemented here is a first step in developing these analytical tools, but is clearly simplistic in that it assumes that the home range of an animal follows a bivariate normal distribution. Although simplistic, our approach did however reveal 2 important facts about the home range of small immature turtles. First, the home ranges were small, and second, they were centered at a distinct depth, around $5 \mathrm{~m}$. This depth selection may be influenced by scalar buoyancy relationships, as has been suggested for resting depth of green turtles at Ascension Island (Hays et al. 2000).

Flipper tagging has shown that at least some juvenile green turtles feeding on macroalgae on the Brazilian coastal shelf undertake ontogenetic migrations, such as has been found for green turtles feeding on seagrass beds (Burnett-Herkes 1974, Bjorndal 1980, Bjorndal \& Bolten 1997). Our sample sizes are small but the fact that larger turtles were the turtles which were observed to move away from the site of capture is in fitting with a model that suggests reduction of growth rates in larger size classes may be the cue to initiate sequential developmental migrations among foraging sites (Bjorndal et al. 2000). We interpret the satellite tracking data in this regard with caution, although the 2 turtles which showed the smallest range movements (Turtles B and C) were the smallest in size and the turtle which travelled the furthest (Turtle F) was among the largest. Turtle A was also small and moved extensively, but there is a possibility that the behaviour of this turtle may have been an artefactual result from displacement and extended captivity.

There are several aspects of the behaviour of Turtle A that are worthy of note. Firstly, the offshore loop shown by the turtle upon release is very similar to that undertaken by a loggerhead turtle in a study of navigational capabilities upon displacement undertaken by Papi et al. (1997). The authors in this case did not suggest causality for the behaviour but we suggest that it may be related to reorientation upon displacement, as Turtle A had been displaced $242 \mathrm{~km}$ from the initial capture site. Secondly, the westward route taken (away from the point of capture) is the one likely to have been taken by all 4 flipper tagged turtles which were recaptured away from Almofala. The only other animals maintained for long periods in captivity were
Turtles $\mathrm{C}$ and $\mathrm{E}$. Turtle $\mathrm{C}$ behaved very similarly to Turtle B, released at approximately the same time, and for Turtle E, transmissions failed after $1 \mathrm{~d}$.

The fact that the turtles generally followed the coast, rarely moving far offshore, is consistent with the manner of coastal migration undertaken by adult female green turtles subject to satellite tracking in Brazil (Hays et al. 2002) and elsewhere (Cheng 2000, Godley et al. 2002b). Given the prevailing fishing methods in the region, with fishing weirs being placed perpendicular to the shore, this helps to explain the relatively high incidental catch when turtles are migrating through this part of the ocean as previously highlighted by Pritchard (1973). Although community participation in conservation is active at our study site, the fact that the 1 migrating turtle was captured and landed within $12 \mathrm{~d}$ at a site further along the coast suggests that without more extensive initiatives throughout the Brazilian fisheries, incidental capture may remain high.

While technological advances have started to illuminate the behaviour of marine turtles while they are at sea, knowledge of juvenile turtles lags behind that of adults. This study helps to redress the balance and suggests that juvenile turtles can be tracked on migrations or for long periods of time on the foraging grounds. Although the location accuracy in the foraging ground is likely to be poor in most cases, meaningful information regarding their distribution can be obtained. Satellite telemetry can very quickly yield many of the data that have been obtained by traditional flipper tagging, and has been inferred from genetic data. As a technique, however, it has constraints in longevity, necessitates a high capital investment and cannot provide important information needed for demographics such as growth rates. We suggest that only through an integrated use of all available technologies will a holistic understanding of marine turtle ecology, and especially of the green turtle juvenile life stages, will be obtained.

Acknowledgements. B.J.G. is a Natural Environment Research Council (NERC) Fellow. This work was supported by grants from: Carnegie Trust for the Universities of Scotland, Darwin Initiative for the Survival of the Species of the UK, Department of Environment, Trade and Regions (DETR), Foreign and Commonwealth Office Environment Fund for the Overseas Territories, Italian Accademia Nazionale dei Lincei, Natural Environment Research Council (NERC), Swedish Science Research Council and Crafoord Foundation. The Projeto TAMAR station in Almofala is supported by the Frankfurt Zoological Society. Projeto TAMAR is officially sponsored by Petrobras, affiliated with IBAMA, and co-managed by Fundação Pró-TAMAR. Helpful comments on an earlier draft were provided by Michael Coyne, Wayne Fuller, Jack Frazier and Corinne Martin. Maps of satellite tracks were produced using 'Maptool', provided without charge by www.seaturtle.org 


\section{LITERATURE CITED}

Argos (1996) User's manual. Argos/CLS, Toulouse

Balazs GH (1980) Synopsis of the biological data on the green turtle in the Hawaiian Islands. NOAA Tech Memo NMFS SWFC-7, Honolulu

Balazs GH, Ellis DM (2000) Satellite telemetry of migrant male and female green turtles breeding in the Hawaiian islands. In: Abreu-Grobois FA, Briseño-Deuñas R, Marquez R, Sarti L (eds) Proc 18th Annu Symp Sea Turtle Biol Conserv. NOAA Tech Memo NMFS-SEFSC-436, US Dept Commerce, Miami, FL, p 53-55

Bass AL, Witzell WN (2000) Demographic composition of immature green turtles (Chelonia mydas) from the east central Florida coast: evidence from mtDNA markers. Herpetologica 56:357-367

Bentivegna F (2002) Intra-Mediterranean migrations of loggerhead sea turtles (Caretta caretta) monitored by satellite telemetry. Mar Biol 141:795-800

Bjorndal KA (1980) Nutrition and grazing behavior of the green turtle, Chelonia mydas. Mar Biol 56:147-154

Bjorndal KA (1997) Foraging ecology and nutrition of sea turtles. In: Lutz PL, Musick JA (eds) The biology of sea turtles. CRC Press, Boca Raton, FL, p 199-232

Bjorndal KA, Bolten AB (1997) Developmental migrations of juvenile green turtles in the Bahamas. In: Keinath JA, Barnard DE, Musick JA, Bell BA (compilers) Proc 15th Annu Symp Sea Turtle Biol Conserv. NOAA Tech Memo NMFS-SEFSC-387, US Dept Commerce, Miami, FL, p 338

Bjorndal KA, Bolten AB, Chaloupka MY (2000) Green turtle somatic growth model: evidence for density dependence. Ecol Appl 10:269-282

Bjorndal KA, Wetherall JA, Bolten A, Mortimer JA (1999) Twenty six years of green turtle nesting at Tortuguero, Costa Rica: an encouraging trend. Conserv Biol 13: 126-134

Bolten AB (1999) Techniques for measuring sea turtles. In: Eckert KL, Bjorndal KA, Abreu-Grobois FA, Donnelly M (eds) Research and management techniques for the conservation of sea turtles. IUCN/SSC Marine Turtle Specialist Group Publication No. 4, Washington, DC, p 110-114

Bolten AB, Balazs GH (1995) Biology of the early pelagic stage - the 'lost year'. In: Bjorndal KA (ed) Biology and conservation of sea turtles. Smithsonian Institution Press, Washington, DC, p 579-581

Boulon RH, Frazer NB (1990) Growth of wild juvenile Caribbean green turtles, Chelonia mydas. J Herpetol 24: 441-445

Bowen BW, Meylan AB, Ross JP, Limpus CJ, Balazs GH, Avise JC (1992) Global population structure and natural history of the green turtle (Chelonia mydas) in terms of maternal phylogeny. Evolution 46:865-881

Brill RW, Balazs GH, Nolland KN, Chang RKC, Sullivan S, George AC (1995) Daily movements, habitat use, and submergence intervals of normal and tumor bearing juvenile green turtles (Chelonia mydas L.) within a foraging area in the Hawaiian islands. J Exp Mar Biol Ecol 185:203-218

Burnett-Herkes J (1974) Returns of green turtles (Chelonia mydas) tagged at Bermuda. Biol Conserv 6:307-308

Carr AF, Carr MH, Meylan AB (1978) The ecology and migrations of sea turtles 7 , the west Caribbean green turtle colony. Bull Am Mus Nat His 162:1-48

Catry P, Barbosa C, Indjai B, Almeida A, Godley BJ, Vie JC (2002) First census of the green turtle at Poilao, Biagos Archipeligo, Guinea-Bissau: the most important nesting colony on the Atlantic coast of Africa. Oryx 36:400-403

Cheng IJ (2000) Post nesting migrations of green turtles (Che- lonia mydas) at Wan-An Island, Penghu Archipeligo, Taiwan. Mar Biol 137:747-754

Deutsch C, Bonde RK, Reid JP (1998) Radio-tracking manatees from land and space: Tag design, implementation, and lessons learned from long-term study. Mar Technol Soc J 32:18-29

Ferreira MM (1968) Sobre a alimentação da aruanã, Chelonia mydas Linnaeus, ao longo da costa do estado do Ceará. Arq Est Biol Mar Univ Fed Ceará 8:83-86

FitzSimmons NN, Limpus CJ, Norman JA, Goldizen AR, Miller JD, Moritz C (1997) Philopatry of male marine turtles inferred from mitochondrial DNA markers. Proc Natl Acad Sci 94:8912-8917

Godley BJ, Broderick AC, Hays GC (2001) Nesting of green turtles Chelonia mydas at Ascension Island, South Atlantic. Biol Conserv 97:151-158

Godley BJ, Broderick AC, Frauenstein R, Glen F, Hays GC (2002a) Reproductive seasonality and sexual dimorphism in green turtles. Mar Ecol Prog Ser 226:125-133

Godley BJ, Richardson S, Broderick AC, Coyne MS, Glen F, Hays GC (2002b) Long-term satellite telemetry of the movements and habitat utilisation by green turtles in the Mediterranean. Ecography 25:352-362

Godley BJ, Broderick AC, Glen F, Hays GC (2003) Postnesting movements and submergence patterns of loggerhead marine turtles in the Mediterranean assessed by satellite tracking. J Exp Mar Biol Ecol 287:119-134

Hatase H, Matsuzawa Y, Sakamoto W, Baba N, Miyawaki I (2002a) Pelagic habitat use by an adult Japanese male loggerhead turtle Caretta caretta examined by the ARGOS satellite system. Fish Sci 68:945-947

Hatase H, Takai N, Matsuzawa Y, Sakamoto W, Omuta K, Goto K, Arai A, Fujiwara T (2002b) Size-related differences in feeding habitat use of adult female loggerhead turtles Caretta caretta around Japan determined by stable isotope analyses and satellite telemetry. Mar Ecol Prog Ser 233:273-281

Hays GC, Adams CR, Broderick AC, Godley BJ, Lucas DJ, Metcalfe JD, Prior AA (2000) The diving behaviour of green turtles at Ascension island. Anim Behav 59:577-586

Hays GC, Åkesson SA, Godley BJ, Luschi P, Santadrian P (2001) The implications of location accuracy for the interpretation of satellite tracking data. Anim Behav 61: $1035-1040$

Hays GC, Broderick AC, Godley BJ, Lovell P, Martin C, McConnell BJ, Richardson S (2002) Bi-phasal long-distance migration in green turtles. Anim Behav 64:895-898

Hendrickson JR (1958) The green turtle Chelonia mydas in Malaya and Sarawak. Proc Zool Soc Lond 130:455-535

Hirth HF (1997) Synopsis of the biological data on the green turtle Chelonia mydas (Linnaeus 1758). Biol Rep 97(1), US Fish and Wildlife Service, US Department of the Interior, Washington, DC

Hughes GR, Luschi P, Mencacci R, Papi F (1998) The 7000 km oceanic journey of a leatherback turtle tracked by satellite. J Exp Mar Biol Ecol 229:209-217

King WF (1982) Historical review of the decline of the green turtle and the hawksbill. In: Bjorndal KA (ed) Biology and conservation of sea turtles. Smithsonian Institution Press, Washington, DC, p 183-188

Lahanas PN, Bjorndal KA, Bolten AB, Encalada SE, Miyamoto MM, Valverde RA, Bowen BW (1998) Genetic composition of a green turtle (Chelonia mydas) feeding ground population: evidence for multiple origins. Mar Biol 130:345-352

Laurent L, Casale P, Bradai MN, Godley BJ, Gerosa G, Broderick AC, Schroth W, Shierwater B, Levy AM, Freggi D, Abd El-Mawla NEM, Hadoud DA, Gomati HE, Domingo 
M, Hadjichristophorou M, Kornaraky L, Demirayak F, Gautier C (1998) Molecular resolution of marine turtle stock composition in fishery bycatch: a case study in the Mediterranean. Mol Ecol 7:1529-1542

Lima EHSM (1999) Captura acidental de tartarugas marinhas em currais de pesca na praia de Almofala-Itarema/Ce: subsidios para a preservação dos quelônios marinhos em áreas de alimentação. MSc thesis, Universidade Federal do Ceará

Lima EHSM, Lagueux CJ, Castro D, Marcovaldi MA (1999) From one feeding ground to another: green turtle migration between Brazil and Nicaragua. Mar Turtle Newsl 85:10

Limpus CJ, Chaloupka M (1997) Nonparametric regression modelling of green sea turtle growth rates (southern Great Barrier Reef). Mar Ecol Prog Ser 144:1-12

Limpus CJ, Miller JD, Parmenter CJ, Reimer D, McLachlan N, Webb R (1992) Migration of green (Chelonia mydas) and loggerhead (Caretta caretta) turtles to and from Eastern Australian rookeries. Wildl Res 19:347-358

Lum LL, Lima EHSM, Santos A (1998) Green turtle tagged in Brazil recovered in Trinidad. Mar Turtle Newsl 82:9

Luschi P, Hays GC, del Seppia C, Marsh R, Papi F (1998) The navigational feats of green sea turtles migrating from Ascension Island investigated by satellite telemetry. Proc R Soc Lond (B) 265:2279-2284

Luschi P, Åkesson S, Broderick AC, Glen F, Godley BJ, Papi F, Hays GC (2001) Testing animal navigational abilities in the ocean: displacement experiments on sea turtles. Behav Ecol Sociobiol 50:528-534

Marcovaldi MA, Marcovaldi GG (1999) Marine turtles in Brazil: the history and structure of Projecto TAMARIBAMA. Biol Conserv 91:35-41

Marcovaldi MA, Baptistotte C, De Castilhos JC, Gallo BMG, Lima EHSM, Sanches TM, Vieitas CF (1998) Activities by Project TAMAR in Brazilian sea turtle feeding grounds. Mar Turtle Newsl 80:5-7

Marcovaldi MA, Gallo BG, Lima EHMS, Godfrey MH (2001) Nem tudo que cai na rede e peixe: an environmental education initiative to reduce mortality of marine turtles caught in artisanal fishing nests in Brazil. Ocean Yearbook 15:246-256

Miller JD (1997) Reproduction in sea turtles. In: Lutz PL, Musick JA (eds) Biology of sea turtles. CRC Press, Boca Raton, FL, p 51-81

Moreira L, Baptistotti C, Scalfone J, Thome JC, De Almeida APLS (1995) Occurrence of Chelonia mydas on the island of Trinidade, Brazil. Mar Turtle Newsl 70:2

Morreale SJ, Standora EA, Spotila JR, Paladino FV (1996) Migration corridor for sea turtles. Nature 384:319-320

Mortimer JA, Carr A (1987) Reproduction and migrations of the Ascension Island green turtle (Chelonia mydas). Copeia 1987:103-113

Musick JA, Limpus CJ (1997) Habitat utilisation and migration in juvenile sea turtles. In: Lutz PL, Musick JA (eds) The biology of sea turtles. CRC Press, Boca Raton, FL, p 137-165

Editorial responsibility: Otto Kinne (Editor), Oldendorf/Luhe, Germany
Nichols WJ, Resendiz A, Seminoff JA, Resendiz B (2000) Transpacific migration of a loggerhead turtle monitored by satellite telemetry. Bull Mar Sci 67:937-947

Ogden JC, Robinson L, Whitlock K, Daganhardt H, Cebula R (1983) Diel foraging patterns in juvenile green turtles (Chelonia mydas L) in St Croix, United States Virgin Islands. J Exp Mar Biol Ecol 66:199-205

Papi F, Luschi P, Crosio E, Hughes GR (1997) Satellite tracking experiments on the navigational ability and migratory behaviour of the loggerhead turtle Caretta caretta. Mar Biol 129:215-220

Parsons JJ (1962) The green turtle and man. University of Florida Press, Gainesville, FL

Plotkin PT (1998) Interaction between behavior of marine organisms and the performance of satellite transmitters: a marine turtle case study. Mar Tech Soc J 32:5-10

Pritchard PCH (1973) International migrations of South American sea turtles (Chelonidae and Dermochelidae). Anim Behav 21:18-27

Pritchard PCH (1976) Post-nesting movements of marine turtles (Chelonidae and Dermochelyidae) tagged in the Guianas. Copeia 1976:749-754

Renaud ML, Carpenter JA (1994) Movements and submergence patterns of loggerhead turtles (Caretta caretta) in the Gulf of Mexico determined through satellite telemetry. Bull Mar Sci 55:1-15

Sakamoto W, Bando T, Nobuaki A, Babam N (1997) Migration path of the adult female and male loggerhead turtles Caretta caretta determined through satellite telemetry. Fish Sci 63:547-552

Schmid JR (1995) Marine turtle populations on the eastcentral coast of Florida: results of tagging studies at Cape Canaveral, Florida, 1986-1991. Fish Bull 93:139-151

Schulz JP (1975) Sea turtles nesting in Suriname. Zool Verh 143:1-143

Seminoff JA, Resendiz A, Nichols WJ (2002) Home range of green turtles Chelonia mydas at a coastal foraging area in the Gulf of California, Mexico. Mar Ecol Prog Ser 242: 253-265

Seraine F (1958) Curral de pesca no litoral cearense. Bol Antropologia (Fortaleza, CE) 2:21-44

Sole G, Medina G (1989) The green turtles of Aves Island. In: Eckert SA, Eckert KA, Richardson TH (Compilers) Proc 9th Annu Workshop Sea Turtle Conservation Biology. NOAA Tech Memo NMFS-SEFC-232, US Dept Commerce, Miami, FL, p 171-173

Tomas J, Castroviejo J, Raga JA (1999) Sea turtles in the south of Bioko Island (Equatorial Guinea). Mar Turtle Newsl 84:4-6

Watson KP, Granger RS (1998) Hydrodynamic effect of a satellite transmitter on a juvenile green turtle (Chelonia mydas). J Exp Biol 201:2497-2505

Wood AG, Naef-Daenzer B, Prince PA, Croxall JP (2000) Quantifying habitat use in satellite-tracked pelagic seabirds: application of kernel estimation to albatross locations. J Avian Biol 31:278-286

Submitted: December 5, 2002; Accepted: February 14, 2003 Proofs received from author(s): April 10, 2003 